\title{
NIUE IN NEW ZEALAND LEGISLATION
}

\author{
Tony Angelo, ${ }^{*}$ Elisabeth Perham, ${ }^{* *}$ Yi-Shen Lau ${ }^{* * * *}$
}

This article provides guidance to non-Niuean lawyers, and particularly for New Zealand lawyers, who want to ascertain the Niue law on a particular matter. The need arises because a New Zealand statute that was extended to be part of the law of Niue may still be in force in New Zealand and in Niue but, because of the passage of time and legislative action in one or both of the countries, the text and effect of the statute may be different in each country.

\section{INTRODUCTION}

This article analyses the New Zealand legislation that refers to Niue and discusses the effect of that legislation. It also contrasts the corresponding position in Niue law, where that is of interest. The article also highlights aspects of the law where there is a lack of clarity and makes some suggestions as to how the law of New Zealand or of Niue might be changed. ${ }^{1}$ After providing some background by way of introduction, this article ${ }^{2}$ analyses the features of the Niue Constitution Act 1974 (in Part III), and the Constitution of Niue in schs 1 and 2 of that Act (in Part IV). In Part V, features of the Niue Act 1966 are analysed. Part VI addresses a range of issues in relation to other New Zealand legislation that relates to Niue.

\section{BACKGROUND}

Niue was part of New Zealand from 1901 to 1974; it was annexed to New Zealand on 11 June 1901. ${ }^{3}$ Upon annexation, laws already in force in Niue as at 11 June 1901 continued in force,

* Professor Emeritus, Victoria University of Wellington.

** Enrolled Barrister and Solicitor of the High Court of New Zealand, BA (Hons) LLB (Hons) (Well), LLM (Harvard), PhD Candidate and Teaching Fellow (UNSW).

*** Enrolled Barrister and Solicitor of the High Court of New Zealand, BA LLB (Hons) (Well).

1 Throughout the article, statutory references are to New Zealand law unless otherwise stated and references to New Zealand are to the state of New Zealand unless otherwise stated.

2 This article had its origin as a draft companion to the piece by Alison Quentin-Baxter on the Cook Islands: Laws of New Zealand Pacific States and Territories: Cook Islands (online ed).

3 By Order in Council dated 13 May 1901 made under the Colonial Boundaries Act 1895 (Imp). The Order in Council came into force on 11 June 1901 as proclaimed by the Governor in "Appointing Date of Extension of Boundaries of Colony to include Cook Group and other Islands" (13 June 1901) 1 New Zealand Gazette 
"including the local laws, customs, and usages of the native inhabitants, in so far as the same are not repugnant to the general principles of humanity". ${ }^{4}$ New Zealand statutes were not in force in Niue unless they were specifically applied. ${ }^{5}$

From 1915 to 1966, Niue was governed under the Cook Islands Act 1915. That Act applied to Niue; the Act did not apply to New Zealand unless otherwise specified. ${ }^{6}$ The Act repealed all New Zealand statute law previously in force in Niue, and provided that New Zealand statutes were not to apply to Niue unless expressly provided. ${ }^{7}$ It provided comprehensively for the governance and legal system in Niue, and set out the substantive law of Niue on a wide range of matters. It also imported into the law of Niue a number of New Zealand statutes, as well as imperial law as at 1840. In Niue, the Cook Islands Act 1915 was replaced by the Niue Act $1966 .^{8}$ The Niue Act 1966 had the same features as the Cook Islands Act 1915. ${ }^{9}$

On 19 October 1974 (Constitution Day), Niue became a self-governing state in free association with New Zealand under the Niue Constitution Act $1974 .{ }^{10}$ The Constitution gave the Niue Assembly

1307. The Governor's Proclamation was dated 10 June 1901. For a full discussion of the legal effect of the Colonial Boundaries Act 1895 (Imp) and the Order in Council made under it in respect of the Cook Islands and Niue, see G Marston and P Skegg "The boundaries of New Zealand in constitutional law" (1988) 13 NZULR 1 at 6-23.

4 Cook Islands and other Islands Government Act 1901, s 2.

5 Cook Islands and other Islands Government Act 1901, ss 2 and 3. This could be done by the Governor by Order in Council on the basis that they "are expedient for the peace, order, good government, and welfare of the inhabitants".

6 Cook Islands Act 1915, s 3.

7 Cook Islands Act 1915, s 618. However, s 615 of the Cook Islands Act 1915 provided that "The law of England as existing on the fourteenth day of January in the year eighteen hundred and forty" continued in force "save so far as inconsistent with this Act or inapplicable to the circumstances of the islands", except that "no Act of the Parliament of England or of Great Britain or of the United Kingdom passed [before that date] shall be in force in the Cook Islands unless and except so far as it [was] in force in New Zealand at the commencement of [the Cook Islands Act 1915]".

8 The commencement date for the Niue Act 1966 was 1 January 1967. On the commencement of the Niue Act, the former law of Niue, earlier repealed by the Cook Islands Act, did not revive: see the Acts Interpretation Act 1924, s 20(4). The Acts Interpretation Act 1924 has since been replaced in both New Zealand law and Niue law, and the corresponding provisions are now the Interpretation Act 1999, s 17(2), and the Interpretation Act 2004 (Niue), s 15(2). For the purposes of the Acts Interpretation Act 1924, the replacement of the Cook Islands Act 1915 by the Niue Act 1966 was required to be treated as if the former had been repealed in relation to Niue (see the Niue Act 1966, s 729(4) as enacted - that section has now been repealed in both New Zealand law and Niue law).

9 Niue Act 1966, s 3: "Except so far as a contrary intention appears, this Act shall apply to Niue only and not to New Zealand".

10 For an account of the process of decolonisation and the development of self-government in Niue, see Terry Chapman The Decolonisation of Niue (Victoria University Press and the New Zealand Institute of 
full law-making power, including the power to amend any legislation that was extended to Niue before self-government. ${ }^{11}$ However, the Queen in right of New Zealand remained the Head of State of Niue; the Governor-General is Her Majesty's representative in relation to Niue. ${ }^{12}$ Niue is part of the Realm of New Zealand. ${ }^{13}$

From Constitution Day, laws of New Zealand no longer applied to Niue. This reflected the fact that Niue had become an autonomous state. However, the laws in force in Niue immediately before Constitution Day (for example, imperial laws as at 1840 and the Niue Act 1966) continued to apply in Niue so far as they were not inconsistent with the Constitution. ${ }^{14}$

Since Constitution Day, the New Zealand Parliament has amended the law of New Zealand with no effect in the law of Niue in most cases. ${ }^{15}$ Similarly, amendments made by the Niue Assembly to the law of Niue have no effect in the law of New Zealand. As a result, the two legal systems have developed independently. For the legal practitioner, this has two key implications.

First, though Niue legislation governing a particular subject may appear at first glance to mirror the New Zealand law on the subject, that is often not the case. A large number of pre-Constitution Day New Zealand statutes are still law in Niue. ${ }^{16}$ However, those statutes may have developed differently in Niue from the way they have been developed in New Zealand. Many of those statutes have been amended in New Zealand law following Constitution Day without those amendments extending to Niue. Further, the Niue Assembly may have amended those statutes post-Constitution Day, but a New Zealand practitioner is unlikely to be familiar with those amendments. Also, a number of the pre-Constitution Day statutes have been retained in Niue law despite their repeal in New

International Affairs, Wellington, 1976). For further historical accounts, see Margaret Pointer Niue 1774 1974: 200 Years of Contact and Change (Otago University Press, Dunedin, 2015) at 277-328, and Terry M Chapman "Modern Times" in Terry M Chapman and others Niue: A History of the Island (University of South Pacific and the Government of Niue, Suva, 1982) 133.

11 Constitution of Niue, art 28. Article 28(3) expressly confers on the Assembly the power to "repeal or revoke or amend or modify or extend, in relation to Niue, any law in force in Niue".

12 Constitution of Niue, art 1 .

13 Letters Patent Constituting the Office of Governor-General of New Zealand 1983, cl 1. The Realm of New Zealand is an entity comprising the countries and territories within the territorial sovereignty of the Queen in right of New Zealand: the State of New Zealand, the self-governing States of the Cook Islands and Niue, Tokelau, and the Ross Dependency. For a discussion of the Realm of New Zealand, see Alison QuentinBaxter and Janet McLean This Realm of New Zealand: The Sovereign, The Governor-General, The Crown (Auckland University Press, Auckland, 2017) at 104-112.

14 Constitution of Niue, art 71 .

15 The exception is New Zealand legislation that applies to Niue at the request and consent of the Niue Assembly as provided for under art 36 of the Constitution of Niue. This is discussed further below.

16 These are listed in Appendix 1. 
Zealand law. Take the Property Law Act 1952 as an example. The New Zealand Parliament passed 10 Property Law Amendment Acts after Constitution Day, none of which was extended to Niue. The Property Law Act 1952 was then repealed in New Zealand law by the Property Law Act 2007. For its part, the Niue Assembly has made substantial changes to the Property Law Act 1952 in Niue law to reflect the fact that there is Crown land and customary land but no private land in Niue. ${ }^{17}$ Thus, the Property Law Act 1952 continues in force in Niue as amended in New Zealand till 1974 and as amended in Niue since 1974.

Secondly, any particular New Zealand law that appears to state the law of Niue cannot and may not be coincident with the actual Niue law. In 2007, an effort was made to amend New Zealand statutes to reflect the fact that many provisions in New Zealand law which purported to apply to Niue no longer had any function, largely because they had been superseded by laws promulgated by Niue. ${ }^{18}$ That notwithstanding, many provisions that relate to Niue are still in New Zealand's statute books.

\section{NIUE CONSTITUTION ACT 1974}

The Niue Constitution Act 1974 is a New Zealand statute that extends to Niue as part of the law of Niue. ${ }^{19}$ In order to emphasise that the guarantees for the people of Niue contained in the Act constitute a directive by the New Zealand Parliament to the executive branch of the New Zealand Government, the Niue Constitution Act contains no provision limiting the extent to which it also applies as part of the law of New Zealand. ${ }^{20}$ However, the Act indicates that the Constitution, as distinct from the Act, has only a limited application in New Zealand. ${ }^{21}$

In New Zealand law, there is no barrier to the repeal or amendment of the Niue Constitution Act 1974 by ordinary Parliamentary processes, ${ }^{22}$ but its alteration in any material respect would be a breach of the terms of the free association relationship unless done with the agreement of the Niue

17 See Legislation (Correction of Errors and Minor Amendments) Act 2004, s 55.

18 For example, the Niue Amendment Act 2007 repealed a large number of the provisions in the Niue Act 1966.

19 Niue Constitution Act 1974, s 2

20 See RQ Quentin-Baxter "Second Report to the Niue Island Assembly on the Constitutional Development of Niue" reproduced at (1999) 30 VUWLR 577 at 581. See the Cook Islands Constitution Act 1964, which was passed when the Cook Islands became self-governing. Section 2(2) of that Act provides: "This Act shall be in force in the Cook Islands and, unless the context otherwise requires, shall apply to the Cook Islands only and not to New Zealand."

21 Niue Constitution Act, s 4(2) does this by authorising and directing any "New Zealand court or department of government or statutory authority" to exercise the functions and powers given to it under the Constitution in accordance with the Constitution.

22 For example, the New Zealand Parliament did not entrench in New Zealand law any provision of the Niue Constitution Act 1974. 
government. In Niue law, the Act is supreme law and, by definition in art 82(1) of the Constitution, is a strongly entrenched part of the Constitution under art 35.

Section 3 of the Act provides that Niue shall be self-governing.

Section 4 of the Act provides that the Constitution in schs 1 and 2 to the Act is to be the Constitution of Niue, and is supreme law. ${ }^{23}$ It also provides that New Zealand courts, departments and statutory authorities must, in exercising their powers under the Constitution, do so in accordance with the Constitution.

In 1983, the governments of New Zealand and Niue acted on the view that nothing in the Niue Constitution Act 1974 or the Constitution had deprived the Queen in right of New Zealand of the prerogative constituent power to issue, "as part of the law of Our Realm of New Zealand, comprising New Zealand, the self-governing state of the Cook Islands, the self-governing state of Niue, Tokelau, and the Ross Dependency", new Letters Patent Constituting the Office of Governor-General of New Zealand. ${ }^{24}$ The preamble to that instrument recited that it had been approved in draft by the government of Niue. Amending Letters Patent, issued on 31 December 1986 and 17 July 2006, were similarly approved in draft. Both instruments have effect as part of the law of the whole of the Realm of New Zealand. ${ }^{25}$ The Letters Patent make it clear that the powers granted in the Letters are to be exercised in each country of the Realm "in accordance with their respective laws and customs." 26

\section{A Citizenship}

\section{Protection of New Zealand citizenship in the Niue Constitution Act 1974}

Section 5 of the Niue Constitution Act 1974 provides that: ${ }^{27}$

23 Niue Constitution Act 1974, s 4(1). Schedule 1 contains the Niuean language version of the Constitution, and sch 2 the English language version.

24 See Letters Patent Constituting the Office of Governor-General of New Zealand 1983, cl 19. The Letters Patent were issued under the prerogative constituent power. As to that power, see Laws of New Zealand Constitutional Law (online ed) at [154] and Quentin-Baxter and McLean, above n 13, at 97-98. As to the continuation of prerogative constituent power in the law of Niue, see Alison Quentin-Baxter and R Q QuentinBaxter Review of the Letters Patent 1917 constituting the Office of Governor-General of New Zealand (The Cabinet Office, Wellington, 1980) at [166]. See Quentin-Baxter and McLean, above n 13, at 95-115 for a discussion of the Letters Patent.

25 Letters Patent Amending Letters Patent Constituting the Office of Governor-General of New Zealand 1987, cl 3; and Letters Patent Amending Letters Patent Constituting the Office of Governor-General of New Zealand 2006, cl 7 .

26 See clauses 1 and 6.

27 Niue Constitution Act 1974, s 5. The constitutional adviser to the Niue Island Assembly had proposed the inclusion in the Bill for the Niue Constitution Act of a more understandable declaratory provision stating that "the people of Niue are to remain New Zealand citizens", but accepted the need to make it clear that the entitlement to New Zealand citizenship would continue to be governed by the British Nationality and New 
Nothing in [the] Act or in the Constitution shall affect the status of any person as a British subject or a

New Zealand citizen by virtue of the British Nationality and New Zealand Citizenship Act 1948.

Section 12 of that Act provided for New Zealand citizenship to be granted on the basis of residence in New Zealand. New Zealand was defined in the Act as including Niue, ${ }^{28}$ so residence in Niue qualified a person for New Zealand citizenship. The Act also provided for citizenship by birth for persons born in New Zealand, ${ }^{29}$ and citizenship by descent for a person born outside New Zealand whose father was a New Zealand citizen. ${ }^{30}$

The inclusion of s 5 in the Niue Constitution Act 1974 means that it retains its constitutional force in the law of Niue and its legal force in the law of New Zealand, as well as signifying the existence of the free association relationship between the two countries. ${ }^{31}$ It is unlikely that Niue would have agreed to free association without the promise of ongoing citizenship, and the assurance of continued support. $^{32}$

\section{Amendments to New Zealand citizenship laws}

The British Nationality and New Zealand Citizenship Act 1948 was repealed by the Citizenship Act 1977. As originally enacted, the latter provided for persons born in New Zealand on or after 1 January 1949 to be New Zealand citizens by birth. ${ }^{33}$ However, the Citizenship Act was substantially amended in 2005 to provide that persons born in New Zealand on or after 1 January 2006 would be citizens by birth only if at least one parent was a New Zealand citizen, or entitled in terms of the Immigration Act 2009 to be in New Zealand indefinitely, or entitled in terms of the Immigration Act

Zealand Citizenship Act 1948: Alison Quentin-Baxter "Niue's Relationship of Free Association with New Zealand" (1999) 30 VUWLR 589 at 589.

28 British Nationality and New Zealand Citizenship Act 1948, s 2.

29 Section 6.

30 Section 7.

31 The Niue Constitutional Review Committee expressed concern that the New Zealand Parliament appeared to be able to change the provisions of its citizenship law in ways that might be detrimental to Niueans: see First Report of the Constitutional Review Committee (Constitutional Review Committee, Niue, 2000) at 23. The concern is justified by the amendments to the substantive provisions of the Citizenship Act 1977 discussed later in this paragraph.

32 See RQ Quentin-Baxter, above n 20, at 581.

33 Citizenship Act 1977, s 6. The provision is subject to limited exceptions: see s 6(2). 
2009 to reside indefinitely in the Cook Islands, Niue or Tokelau. ${ }^{34}$ Persons born outside New Zealand after 1 January 1978 are citizens by descent if one parent is a citizen otherwise than by descent. ${ }^{35}$

Section 8 of the 1977 Act provides for citizenship by grant to persons who are entitled to be in New Zealand indefinitely and are present in New Zealand (and entitled to be in New Zealand) for a specified number of days in the five years before the application for citizenship is made. The person must intend to continue to reside in New Zealand. Under s 8(4), the Minister of Internal Affairs of New Zealand (after consultation with the Minister of Immigration of New Zealand) may waive the requirement that an applicant be entitled to be in New Zealand indefinitely, if the applicant is entitled to reside indefinitely in Niue. The Minister may also waive the requirement that an applicant be present in New Zealand for a certain number of days in the previous five years, if the applicant was present in Niue for that same number of days in the five previous years. However, there is no provision to waive the requirement that the applicant must intend to continue to reside in New Zealand, so the usefulness of s 8(4) for a Niue resident is limited.

\section{Impact of amendments on citizenship guarantee}

Despite the repeal of the British Nationality and New Zealand Citizenship Act 1948, the reference to that Act in the Niue Constitution Act 1974 was not updated to refer to the Citizenship Act 1977, either in New Zealand law or in Niue law.

In New Zealand law, it might be argued that references to the 1948 Act can now be read as references to the 1977 Act. That is because the Interpretation Act 1999 provides that a legislative reference to a repealed enactment is a reference to the enactment that modifies, replaces, or corresponds to the repealed enactment. ${ }^{36}$ However, the Interpretation Act 1999 plays only a default role: it does not apply where a particular enactment provides otherwise, or the context of particular enactment requires a different interpretation. ${ }^{37}$ It is notable in that context that at the time of enactment, the 1977 Act contained a schedule setting out specific consequential amendments to a number of New Zealand statutes; ${ }^{38}$ the Niue Constitution Act 1974 was not included in that schedule. This suggests that it was not intended that the reference to the 1948 Act in s 5 would change on the enactment of the 1977 Act. Further, Chief Parliamentary Counsel has not updated the reference in the

34 Citizenship Act 1977, s 6 as amended by s 5 of the Citizenship Amendment Act 2005.

35 Section 7. The Citizenship Amendment Act 2005 also made provision for citizenship by descent for children of persons who are citizens by descent if the child would otherwise be stateless.

36 Interpretation Act 1999, s 22.

37 Section 4(1).

38 Citizenship Act 1977, sch 3. 
official reprints of the Act, ${ }^{39}$ despite the fact that the Legislation Act 2012 allows updates to be made to reprints of legislation "to show the effect of any amendment or repeal"; 40 making such changes is the usual practice.

In respect of Niue law, the argument might also be made that the reference in s 5 to the 1948 Act can now be read as a reference to the 1977 Act by virtue of the Interpretation Act 2004 (Niue). ${ }^{41}$ However, amendments to the Constitution of Niue ${ }^{42}$ can be made only by meeting the heightened amendment requirements of art 35 of the Constitution. In relation to amendments to certain provisions of the Niue Constitution Act 1974 (Niue), including the citizenship provision, those requirements include not only that the amendment receive the affirmative vote of two-thirds of the members of the Niue Assembly (the requirement for all constitutional amendments), but also that it receive the affirmative vote of two-thirds of the validly cast votes at a poll of electors.

The Cook Islands Court of Appeal decision in Henry v Attorney-General is persuasive authority for the proposition that all changes to deeply entrenched provisions of the Niue Constitution Act 1974 (Niue) (such as s 5) which can be described as "truly an amendment[,] modification or extension" must comply with those stringent amendment requirements. ${ }^{43}$ That case related to amendments to the Constitution of the Cook Islands that changed all references to "Premier" to references to "Prime Minister", which met the requirements for amendments to shallowly entrenched provisions of the Constitution, but not the requirements for amendments to the heavily entrenched external affairs and defence provision in the Cook Islands Constitution Act 1964 (CI). ${ }^{44}$ The Court held that the terms Prime Minister and Premier were synonymous for the purposes of the relevant section, and so the amendment was simply a change in nomenclature and did not change the substance of the section. Therefore, the change did not require compliance with the stringent amendment processes for changes to the Cook Islands Constitution Act 1964 (CI). However, even assuming the validity of the approach

39 See Parliamentary Counsel Office "New Zealand Legislation" <legislation.govt.nz>; and the Legislation Act 2012, ss 16 and 18 .

40 Legislation Act 2012, s 25(1)(m).

41 Section 20(2) of that Niue Act provides: "A reference in an enactment to a repealed enactment is a reference to an enactment which, with or without modification, replaces, or corresponds to, the enactment repealed."

Prior to that, the same argument could be made by reference to the Acts Interpretation Act 1924 (Niue), s 21:

In every unrepealed Act in which reference is made to any repealed Act such reference shall be construed as referring to any subsequent enactment passed in substitution for such repealed Act, unless it is otherwise manifested by the context.

42 Which includes the Niue Constitution Act 1974 (Niue): art 82, definition of "Constitution".

43 Henry v Attorney-General [1985] LRC (Const) 1149 (Cook Islands CA) at 1152-1153.

44 Those requirements, which are contained in art 41 of the Constitution of the Cook Islands, are almost identical to those contained in art 35 of the Constitution of Niue. 
in Henry, a strong argument can be made that a change from a guarantee of New Zealand citizenship by virtue of the British Nationality and New Zealand Citizenship Act 1948 is different in substance from a guarantee of New Zealand citizenship by virtue of the Citizenship Act 1977: such a change would be "truly an amendment" and not simply a change in nomenclature.

If the citizenship guarantee in s 5 of the Niue Constitution Act 1974 in both New Zealand and Niue law still refers to the British Nationality and New Zealand Citizenship Act 1948, the question arises as to what s 5 now means. There are number of possibilities, including: ${ }^{45}$

(a) The constitutional guarantee of New Zealand citizenship for Niueans is effectual only to the extent that the rights of Niueans to New Zealand citizenship are found only in the Citizenship Act 1977. Such a reading is inconsistent with the relationship of free association.

(b) The Niue Constitution Act 1974 still protects for Niueans the rights they had under the British Nationality and Citizenship Act 1948. The key differences between the 1977 Act and the 1948 Act include, for example, a change from citizenship by birth to citizenship by descent, and from citizenship by descent being passed down only by the father to citizenship by descent being passed down by either parent.

A literal reading of the Niue Constitution Act 1974 would be likely to lead to accepting that the second possibility described above is correct. However, that solution is not workable, and does not seem to reflect the intentions of New Zealand and Niue when they entered the relationship of free association. In practical terms, New Zealand citizenship is governed by New Zealand legislation. It would be desirable for the legislatures of both Niue and New Zealand to amend their respective laws to reflect that reality.

\section{Inconsistencies between Niue law and New Zealand law relating to citizenship}

There are two areas where differences in Niue law and New Zealand law have the potential to cause confusion. The first relates to the Citizenship Act 1977 in Niue law. The Act was extended to Niue by the request and consent of the Niue Assembly following the procedures outlined in art 36 of the Constitution. Article 36 provides that the New Zealand Parliament can legislate for Niue only where the Niue Assembly has requested and consented to such enactment by resolution, the Citizenship Act 1977 expressly declares that the Assembly did so. ${ }^{46}$ The Citizenship Act 1977 has been amended by the New Zealand Parliament since 1977; the art 36 request and consent process was not used in respect of any of the amendments and the Act has not been amended by the Niue Assembly. As a result, the Citizenship Act 1977 as Niue law remains as enacted in New Zealand in 1977, and therefore differs significantly from the law in New Zealand. As indicated above, the disparity has no

45 These interpretations are discussed in greater detail in Elisabeth Perham "Citizenship Laws in the Realm of New Zealand" (2011) 9 NZ YB Int'l Law 219 at 225-231.

46 Citizenship Act 1977, s 29(2). 
practical effect as it for the state of New Zealand to grant and regulate its citizenship. However, given the importance of citizenship to Niue, it would be preferable for the statute in Niue law to be consistent with reality.

The second relates to the mode by which the Citizenship Act 1977 was extended to Niue. The relevant part of s 29 reads:

(1) Whereas in accordance with Article 36 of the Constitution of Niue (as set out in Schedule 2 to the Niue Constitution Act 1974) the Niue Assembly has by resolution requested and consented to the enactment of a provision extending all of the provisions of this Act to Niue as part of the law of Niue: Be it therefore enacted as follows:

The Niue Act 1966 is hereby amended by inserting, after section 684, the following section:

"684A Citizenship Act in force in Niue

The Citizenship Act 1977 shall extend to and be in force in Niue."

In New Zealand law, s 29(2) had the effect of amending the Niue Act 1966 by inserting a new s 684A. In Niue law, the Citizenship Act 1977 was extended to Niue but the Niue Act 1966 was not amended in Niue law because the art 36 requirements of the Niue Constitution for the extension of legislation to Niue by the New Zealand Parliament were not met. ${ }^{47}$ That is to say, reference to the Niue Act was unnecessary to achieve the purpose. Section 684A of the Niue Act 1966 was repealed in Niue law in 2004 and in New Zealand law in 2007 because the provisions were spent. This did not affect the Citizenship Act in Niue law.

\section{References to "New Zealand citizens" in New Zealand legislation}

References to "New Zealand citizens" in other New Zealand enactments apply, prima facie, to all citizens but, in some cases, there may be a question whether a particular provision is intended to apply to New Zealand citizens who are Niuean residents. ${ }^{48}$ In drafting legislation applying to citizens, there is a need to consider the policy implications of any provision that would have such an effect outside New Zealand. ${ }^{49}$

47 See further discussion of art 36 below in relation to the New Zealand Representative, the Seal of New Zealand Act 1977, and the Misuse of Drugs Act 2007 (Niue).

48 For example, a number of provisions in the Crimes Act 1961 apply extraterritorially to New Zealand citizens or persons ordinarily resident in New Zealand but the provisions are not Niue law. In respect of these Acts, there may be a question as to whether the New Zealand law should cover the conduct of a Niue resident committed outside New Zealand or Niue, or whether it is Niue law that should cover that conduct. As to persons having the status of permanent residents of Niue, see the Immigration Act 2011 (Niue).

49 Consider the hypothetical situation of compulsory military service for New Zealand citizens being reintroduced. If the necessary provision in New Zealand law were to purport to apply to New Zealand citizens whose home is Niue, it would be both inconsistent with the self-government of Niue, as well as unenforceable. 


\section{B Responsibility for External Affairs and Defence of Niue}

Section 6 of the Niue Constitution Act 1974 provides: ${ }^{50}$

Nothing in this Act or in the Constitution shall affect the responsibilities of Her Majesty the Queen in right

of New Zealand for the external affairs and defence of Niue.

In New Zealand constitutional law, the provision preserves the executive authority of New Zealand to exercise responsibilities for the external affairs of Niue. Nothing prevents the government of Niue from exercising responsibility for those matters in its own right. In addition, the provision does not give the New Zealand parliament or government any legislative or executive power within Niue. ${ }^{51}$

Section 8 of the Niue Constitution Act 1974 requires effect to be given to s 6 through positive cooperation between New Zealand and Niue, after consultation between the Prime Minister of New Zealand and the Premier of Niue, and in accordance with the policies of their respective governments. If it appears desirable that any provision be made in the law of Niue to carry out these policies, that provision may be made in the manner prescribed by the Constitution, but not otherwise. ${ }^{52}$

\section{Entering into treaties}

The New Zealand government's practice has been to take a treaty action in respect of Niue only at its request or with its express agreement. ${ }^{53}$ The requirement that effect be given to s 6 "after consultation between the Prime Minister of New Zealand and the Premier of Niue" might suggest that the New Zealand government is free to act internationally for Niue, even though the consultation does not result in agreement. ${ }^{54}$ However, s 8 of the Niue Constitution Act 1974 provides a further

However, the Niue government and Assembly might, in time of need, itself decide or agree to take parallel measures. Section 6 leaves open the way in which the sovereign is to be advised in the particular case.

50 A reference to "Her Majesty the Queen in right of New Zealand" can either mean the Queen in right of the State of New Zealand, or in right of the Realm of New Zealand: see Letters Patent Constituting the Office of Governor-General of New Zealand 1983, cl 1 and explanation above n 13. The reference in s 6 of the Niue Constitution Act 1974 means the Queen as advised by her New Zealand Ministers, ie the Queen in right of the State of New Zealand.

51 For example, s 3 of the Niue Constitution Act 1974 is clear that Niue is a self-governing state. Under the Constitution of Niue, New Zealand has no power to legislate for Niue without the request and consent of the Niue Assembly: art 36.

52 The original purpose of the provision was to make it clear that s 6 of the Niue Constitution Act 1974 did not reserve the former authority of the New Zealand Parliament to make laws extending to Niue as part of its law without observing the requirements of art 36 of the Constitution.

53 The New Zealand government has taken the same approach in respect of the Cook Islands. See Laws of New Zealand Pacific States and Territories: Cook Islands (online ed) at [29].

54 Niue Constitution Act 1974, s 8. 
safeguard, ${ }^{55}$ through the requirement that effect is to be given to s 6 of that Act "in accordance with the policies of their respective governments".

If New Zealand becomes bound by a treaty in respect of Niue, it must rely exclusively on the Niue government to implement the treaty obligation in one of the following ways:

(a) through legislation passed by the Niue Assembly;

(b) through legislation passed by the New Zealand Parliament acting at the request and with the consent of the Niue Assembly; or

(c) through administrative action taken in the exercise of Niue's own executive authority.

Until 1946, New Zealand treaties, including those inherited from the United Kingdom and applying to the Cook Islands, were regarded as applying also to Niue unless application to Niue was expressly excluded. After 1946 and until attainment of self-government, a New Zealand instrument of ratification of, or accession to, a treaty containing a colonial application clause referred to its application to "the Cook Islands (including Niue)" or "the Cook Islands (excluding Niue)". ${ }^{56}$ In the absence of such a reference, the treaty did not apply to the Cook Islands or Niue. ${ }^{57}$ A New Zealand treaty that did not contain a colonial application clause applied to Niue if, by its terms, it was applicable to the whole territory of New Zealand (including the territories for whose international relations New Zealand was responsible).

After Niue's attainment of self-government on 19 October 1974 and until 10 November 1988, bilateral treaties entered into by the government of New Zealand usually provided explicitly for their application or non-application to Niue $;^{58}$ multilateral treaties were usually silent on the extent of their territorial application. ${ }^{59}$ The terms of standard-form territorial application clauses contained in some

55 Section 8 applies also to s 5.

56 This was because, until the Niue Act 1966 came into force, Niue was administered under the Cook Islands Act 1915 as part of the "Cook Islands" as defined in that Act. In 1946, New Zealand recognised the Cook Islands and Niue as separate non-self-governing territories for the purposes of art 73(e) of the Charter of the United Nations. Therefore, after 1946, although Niue was still administered as part of the Cook Islands, New Zealand adopted the practice of referring in ratification instruments to the territories as entities separate from New Zealand.

57 By the early 1960s, the Cook Islands was approaching self-government and the Cook Islands and Niue began to be referred to as separate entities in the context both of the application of treaties and for other purposes of international law.

58 For bilateral treaties entered into during the relevant period and applying to Niue, see the New Zealand Consolidated Treaty List as at 31 December 1996, [1997] NZTS 1, vol 2 (Bilateral Treaties). Some bilateral treaties not immediately applicable to Niue contain provision for their subsequent application, either by simple notification or on terms to be agreed with the other party.

59 A notable exception is the United Nations Convention on the Law of the Sea. This was signed by Niue in late 1982, ostensibly under a provision permitting signature by self-governing associated states which had chosen that status in an act of self-determination supervised and approved by the United Nations, which had 
treaties, particularly before the decolonisation era, did not distinguish between self-governing associated states and non-self-governing territories. Where the treaty itself is silent as to territorial application, the Vienna Convention on the Law of Treaties governs such application. The Convention provides that "[u]nless a different intention appears from the treaty or is otherwise established, the treaty is binding upon each party in respect of its entire territory". ${ }^{0}$ The New Zealand government interpreted this provision to mean that the state of New Zealand could not become a party to a multilateral treaty unless the Cook Islands and Niue agreed that the treaty would also apply to the territory of their respective states.

In 1981, the New Zealand government adopted the practice of including, in instruments ratifying, acceding to, or accepting a general multilateral treaty applying to the Cook Islands or Niue, a statement recording that the government of the associated state concerned had requested the extension of the treaty to its territory.

On 10 November 1988, the New Zealand government changed its treaty practice by declaring that future treaties entered into by the government of New Zealand would no longer extend to the Cook Islands or Niue unless expressly signed, ratified, accepted, approved or acceded to on behalf of the associated state concerned. This declaration was lodged with the Secretary-General of the United Nations and circulated among all member of the United Nations, as well as specialised agencies. ${ }^{61}$

As a result of the declaration, multilateral treaties entered into by New Zealand after 10 November 1988, and designating the Secretary-General of the United Nations as depositary, extend to Niue only if such extension is indicated by the relevant treaty instrument. Niue may also withdraw the territorial limitation subsequent to New Zealand entering into a treaty.

The 1988 declaration did not preclude New Zealand treaty actions on behalf of Niue with the consent of the government of Niue. The declaration did not prevent the recognition of Niue's capacity itself to enter into treaties to which it was eligible to become a party. The new approach did accelerate the process of Niue's assumption of responsibility for the conduct of its international relations in its own right. When requested to do so, the New Zealand government has made statements putting on record Niue's authority and capacity to enter into international treaties in its own right. ${ }^{62}$

competence over the matters governed by the Convention, including the competence to enter into treaties in respect of those matters.

60 Vienna Convention on the Law of Treaties 1155 UNTS 331 (opened for signature 23 May 1969, entered into force 27 January 1980), art 29.

61 This declaration was circulated as UNGA LE 222 New Zealand.

62 See for example Committee on the Rights of the Child Initial Report of States parties due in 1998: Niue CRC/C/NIU/1 (2010) at [63]-[64]:

... it is important to note that the responsibilities of the New Zealand government in relation to Niue's external affairs and defence are based on the delegated authority of the Niuean Government. Full 


\section{Defence}

Alongside external affairs, s 6 of the Niue Constitution Act 1964 preserves a responsibility on the part of the New Zealand government for the defence of Niue. ${ }^{63}$ As with external affairs, the existence of this responsibility does not affect Niue's own executive authority in respect of defence.

In New Zealand law, the Defence Act 1990 designates Niue as an area for whose defence the Governor-General, on the Sovereign's behalf, ${ }^{64}$ "may ... raise and maintain armed forces, either in New Zealand or elsewhere". ${ }^{65}$ Under the Defence Act, armed forces can also be raised and maintained, in New Zealand or elsewhere, for certain other purposes that might foreseeably have an application to Niue. Those purposes are:

(a) the protection of New Zealand's interests; 66

(b) the provision of assistance to the civil power in time of emergency; ${ }^{67}$ and

(c) the provision of a public service. ${ }^{68}$

However, the Defence Act does not extend to Niue as part of the law of Niue, and it is not authority for the raising and maintaining of armed forces in Niue by either the government of New Zealand or the government of Niue. ${ }^{69}$ The presence of members of the New Zealand armed forces in Niue therefore requires the agreement of the government of Niue. The two governments entered into such

legislative and executive powers are vested in the legislature and Government of Niue. Niue has full constitutional capacity to conduct its own external affairs and to enter into treaties. Since November 1988, New Zealand's signature and ratification of a treaty does not affect Niue unless Niue expressly requests it to.

See also Ministry of Foreign Affairs and Trade "Diplomatic Note from the Government of New Zealand to the Government of the United States" (5 March 1996) reproduced in United States Department of State Bureau of Oceans and International Environmental and Scientific Affairs "Limits in the Seas No 119: Maritime Boundary: Untied States - Niue" (July 1997) at Annex 2.

63 As noted above at $\mathrm{n}$ 50, the reference in s 6 to the Queen in Right of New Zealand should be read as a reference to the state, and not to the Realm, of New Zealand.

64 Ie the Governor-General and Sovereign in right of the state of New Zealand.

65 Defence Act 1990, s 5.

66 Section $5(\mathrm{~b})$.

67 Section 5(e).

68 Section 5(f).

69 Note that in New Zealand law some of the provisions of the Defence Act apply in certain circumstances to New Zealand citizens outside New Zealand (see s 4 of the Act). This would include New Zealand citizens in Niue. 
an agreement in 1988 in respect of a training exercise in Niue. ${ }^{70}$ The Visiting Forces Act 1939, largely still in its form as at 19 October 1974 (ie Constitution Day), is in force in Niue as part of its law. ${ }^{71}$ Amendments to the law by the Niue Assembly in 2004 have clarified that where the New Zealand armed forces are lawfully present in Niue with the consent of the Niue government, the New Zealand military courts and authorities may exercise, in relation to discipline and internal administration, the powers conferred on them by New Zealand law. ${ }^{72}$

For the purposes of s 5 of the Official Information Act 1982: ${ }^{73}$

Good reason for withholding information exists ... if the making available of the information would be likely - (a) to prejudice the security or defence of the self-governing State of Niue.

Presumably, the provision applies whether Niue's security or defence is being protected by actions of the New Zealand government, or actions of the government of Niue about which an agency of the New Zealand government holds information.

\section{Economic and Administrative Assistance}

Section 7 of the Niue Constitution Act provides that "[i]t shall be a continuing responsibility of the Government of New Zealand to provide necessary economic and administrative assistance to Niue." Section 8 of the Niue Constitution Act requires effect to be given to 57 through:

... positive co-operation between New Zealand and Niue, after consultation between the Prime Minister of New Zealand and the Premier of Niue, and in accordance with the policies of their respective governments; and, if it appears desirable that any provision be made in the law of Niue to carry out these policies, that provision may be made in the manner prescribed by the Constitution, but not otherwise.

The reference in s 7 of the Niue Constitution Act to a "continuing" responsibility could simply mean "continuing in spite of the fact that Niue is to be self-governing", although that would have been clear enough even if the word had been omitted. At the least, the use of the word "continuing" impliedly acknowledged the likelihood that Niue would continue to be dependent on New Zealand's economic and administrative assistance for the foreseeable future. Arguably, a "continuing"

70 Exchange of Notes Constituting an Agreement Between the Government of New Zealand and the Government of Niue on Arrangements for Visits by Contingents of New Zealand's Armed Forces to Niue for Exercise Joint Venture 88 [1988] NZTS 5 (signed 26 April 1988, entered into force 26 April 1988).

71 New Zealand amended the Visiting Forces Act in 1981 and 1997 and passed a new Visiting Forces Act in 2004, repealing the Visiting Forces Act 1939. As the relevant Acts were not passed at the request and with the consent of the Niue Assembly and do not purport to extend to Niue as part of its law, pursuant to art 36 of the Constitution of Niue, they are not part of Niue law.

72 Visiting Forces Act, ss 2 and 3(1), as amended by the Legislation (Correction of Errors and Minor Amendments) Act 2004 (Niue).

73 Official Information Act 1982, s 7(a)(ii). 
responsibility means a responsibility to be discharged through the provision of economic and administrative assistance, of the same kind, and in the same way, in the future as in the past, so far as is consistent with the mechanisms for the implementation of the guarantee established by s 8 . The point has also been made that a "continuing" responsibility means one that cannot be discharged by a one-off contribution, or a contribution for a limited period, or only so long as certain conditions are complied with - a concept that has particular relevance to the concerns that have been voiced about the per capita cost of New Zealand assistance to Niue in comparison with the assistance provided to independent Pacific island states. ${ }^{74}$ In that context, a "continuing" responsibility must mean continuing as long as there are people living in Niue under a constitution for self-government and in a relationship of free association with New Zealand. ${ }^{75}$

The reference to "necessary" economic and administrative assistance is clearly the vehicle for taking into account all the relevant factors when making decisions about the long term purpose, the short-term objectives, and the kinds and the amounts of assistance that the New Zealand government should provide. In deciding what is "necessary", s 8 of the Niue Constitution Act requires the policies of the two governments to be brought to bear, both at the official level and, ultimately, in consultations between the Prime Minister of New Zealand and the Premier of Niue. That requirement, and the further requirement that effect be given to s 7 of the Niue Constitution Act through "positive cooperation" between New Zealand and Niue, make it clear that neither government has the right to insist that its own policies prevail.

The further question is how far the outcome of the consultative process is pre-determined by the responsibility under s 7 to provide "necessary" assistance. Such a responsibility implies that the assistance is required for particular purposes, but in formulating their policies about what those purposes should be, how they should be achieved and what kinds and amounts of economic and administrative assistance are necessary to achieve the desired ends, the two governments must make

74 However, in a 2010 report on New Zealand's relationships with South Pacific Countries, the Foreign Affairs, Defence and Trade Committee recognised New Zealand's special constitution relationship with Niue and determined that the relationship warranted different handling from normal aid relationships. The Committee recommended an assistance strategy in Niue designed to bring the standard of basic services in Niue into line with New Zealand standards over time, on the basis that there should not be communities of New Zealand citizens overseas "receiv[ing] lower standards of basic services than New Zealanders living in similar-sized population centres in New Zealand". However, note that despite recognising the special nature of New Zealand's relationship with Niue, the Committee appeared to regard assistance to Niue as aid rather than as a constitutional obligation. See Foreign Affairs, Defence and Trade Committee Inquiry into New Zealand's relationship with South Pacific countries (10 December 2010) at 9, 14, 21-22, and 27-31. For a critique of the report see Tony Angelo and Elisabeth Perham "Report of the Foreign Affairs, Defence and Trade Committee on New Zealand's Relationship with South Pacific Countries" (2010) 8 NZ Yearbook of International Law 181.

75 Alison Quentin-Baxter "Niue's Relationship of Free Association with New Zealand", above n 27, at 598. 
value judgements. In doing so, they are bound to look to the Constitution for such guidance as it can give. Two articles are especially relevant.

Article 61 of the Constitution sets out the responsibilities of the government of Niue to make provision for such health and education institutions and services as it considers necessary to provide for public health and for educational opportunities for the people of Niue. ${ }^{76}$ It is also responsible for: ${ }^{77}$

... establishing and maintaining such other institutions and services and for making such other provision

as it considers necessary to provide a reasonable standard of living for the people of Niue and to secure

their economic, social, and cultural welfare.

The use of the word "necessary" throughout art 61, as a measure of the provision that the government of Niue is required to make for the purposes specified, is consistent with its use in $\mathrm{s} 7$ of the Niue Constitution Act 1974. Similarly, art 69(3) of the Constitution sets out the factors which must be taken into account in settling the terms and conditions of employment in the Niue Public Service. In so far as art 69 is contained in an Act of the New Zealand Parliament, it is, in some degree, evidence of a New Zealand commitment to give material support. The same comment can be made in respect of art 61. The constitutional provisions are indicative of some of the purposes for which economic and administrative assistance may be necessary, but they are not limiting. Other objectives, such as the availability of adequate sea and air transport between Niue and the outside world, may be just as important. ${ }^{78}$

More generally, but no less importantly, ss 7 and 8 of the Niue Constitution Act must be interpreted and applied consistently with other important sections of that Act, including the provisions providing that Niue is to be self-governing (s 3) and that Niueans are to retain their New Zealand citizenship (s 5). In the context of the continuing responsibility to provide "necessary economic assistance to Niue", the four provisions, read together, are authority in New Zealand law for revenue raised by Parliament from citizens in New Zealand to be expended for the benefit of fellow citizens in Niue, in accordance with the decisions of the Niue Assembly. ${ }^{79}$ The object of self-government was to give the democratically elected Niue Assembly the power to make the decisions about the priorities to be followed in the spending of the resources made available to it for the benefit of the Niuean people. Accordingly, while the use made of the funds provided will always be relevant to negotiations

76 Niue Constitution Act, arts 61(1) and (2).

77 Article 61(3)

78 See Report of the Joint New Zealand/Niue Review Group to the Prime Minister of New Zealand and to the Premier of Niue (Niue Review Group, Wellington and Alofi, August 1986) at recommendations 19 and 20 [Report of the Joint Review Group].

79 See generally Alison Quentin-Baxter "Niue's Relationship of Free Association with New Zealand", above n 27. 
about the provision of further funds, the New Zealand government should not use its power of the purse in a way that removes the power of decision-making from the Niue Assembly. ${ }^{80}$

\section{New Zealand Representative in Niue}

Section 9 of the Niue Constitution Act provides that: "The New Zealand Representative shall be stationed in Niue, and shall be the representative of the Government of New Zealand in Niue." ${ }^{81}$ At the time the Constitution Act was being drafted, the people of Niue regarded the presence of a New Zealand Representative in Niue as the "best evidence of New Zealand's continued interest in Niue." 82 The Niue Island Assembly therefore requested that provision for the office should be included in the Niue Constitution Act. The relevant provision is a term of the free association between New Zealand and Niue, as well as being part of each country's law.

Since 1981, Niue has accorded to the New Zealand Representative in Niue, and to the staff of the office, diplomatic privileges and immunities in accordance with the Vienna Convention on Diplomatic Relations. ${ }^{83}$ The fact that, at the time, the office of the New Zealand Representative in Niue was not regarded as a diplomatic mission required special provision for that purpose to be made in the law of Niue. ${ }^{84}$

80 See also Alison Quentin-Baxter "The New Zealand Model of Free Association: What does it mean for New Zealand" 39 VUWLR 607.

81 Niue Constitution Act, s 9(2): The provision probably owes its origin to the fact that the Cook Islands Constitution had originally made provision for the office of High Commissioner who was to represent both the Queen and the New Zealand government in the Cook Islands. By the time the Niue Island Assembly was settling the terms of Niue's free association with New Zealand, this arrangement had been found to be unworkable, and the separate office of New Zealand Representative had been created to represent the New Zealand government in the Cook Islands. See further Laws of New Zealand Pacific States and Territories: Cook Islands (online ed) at [33]. But although the office of New Zealand Representative in the Cook Islands had its origin in the Cook Islands Constitution, the maintenance of that office is not seen as a term of the free association between New Zealand and the Cook Islands.

82 RQ Quentin-Baxter "Second Report to the Niue Island Assembly on the Constitutional Development of Niue" (1999) 30 VUWLR 577 at 582.

83 Vienna Convention on Diplomatic Relations 500 UNTS 95 (opened for signature 18 April 1961, entered into force 24 April 1986).

84 New Zealand Representative Act 1981 (Niue). The Consular Immunities (Niue) Order 1994 extended consular immunity to the Niue Consul-General in Auckland, and Niue's consular employees (see cl 3(1)). In New Zealand law, s 2 of the Diplomatic Privileges and Immunities Act 1968 was amended in 1985 to clarify that, for the purposes of that Act, "State" includes the Cook Islands and Niue: Diplomatic Privileges and Immunities Amendment Act 1985, s 2. When Niue established a High Commission in Wellington, the Diplomatic Immunities (Niue) Order 2001 confirmed the diplomatic immunity of the Niue High Commissioner, the diplomatic staff, and the families of the High Commissioner and diplomatic staff (cl 4(1)) notwithstanding the fact that they may be New Zealand citizens (cl 4(2)). 
In Niue law, the Niue Constitution Act provides that the New Zealand Representative in Niue is to be appointed under the State Services Act $1962 .{ }^{85}$ That section, s 9 in New Zealand law, now provides that the Representative is to be appointed under the State Sector Act $1988 .{ }^{86}$ That is because, when enacted by New Zealand, the State Sector Act 1988 repealed and replaced the State Services Act 1962. The State Sector Act 1988 was in turn repealed by the Public Service Act 2020. In the Bill for the Public Service Act 2020, an amendment was scheduled to s 9 of the Niue Constitution Act; that amendment was not enacted. None of the Acts of 1962, 1988 or 2020 have ever been part of Niue law. The 1988 Act was not extended to Niue under the request and consent provisions of art 36 of the Constitution. As with the interpretation of s 5 of the Niue Constitution Act relating to citizenship discussed above, the resolution of this discrepancy is an open question. For the purposes of the Niue Constitution Act, the relevant change in s 9 relates to the appointment of the New Zealand Representative. If the reference in s 9 is read as being a reference to the 1962 Act, the appointment of the New Zealand Representative would be made by the States Services Commission, ${ }^{87}$ excluding the possibility of a political appointment. ${ }^{88}$ If it is read as a reference to the 1988 Act, the power to appoint the Representative rests with the Chief Executive of the Ministry of Foreign Affairs and Trade. ${ }^{89}$

The difference between the positions in Niue law and New Zealand law might be resolved by the application of s 20(2) of the Interpretation Act 2004 (Niue), which provides that a reference in an enactment to a repealed enactment is a reference to an enactment which, with or without modification, replaces, or corresponds to, the enactment repealed..$^{90}$ On that view, the reference to the State Services Act 1962 in the Niue Constitution Act as it stands in Niue law could now be read as a reference to the Public Service Act 2020. However, s 20(2) applies only to legislation of Niue that replaces or corresponds to the repealed enactment, but not to legislation passed by New Zealand. To interpret the section otherwise would be inconsistent with the fact that the New Zealand Parliament cannot legislate for Niue except at the request and consent of the Niue Assembly. ${ }^{91}$

85 Niue Constitution Act (Niue), s 9(1).

86 Niue Constitution Act, s 9(1).

87 A body of up to four persons appointed by the Governor-General in Council on the recommendation of the Prime Minister: see State Services Act 1962, a 3(1).

88 State Services Act 1962, s 26(1).

89 State Sector Act 1988, s 59. That position is maintained by s 66 of the Public Service Act 2020. As the head of an overseas mission, the New Zealand High Commissioner in Niue would formally be appointed by the Governor-General in accordance with s 4 of the Foreign Affairs Act 1988.

90 Prior to 2004, the equivalent section was s 21(1) of the Acts Interpretation Act 1924 (Niue), which stated that a reference in an unrepealed Act to a repealed Act "shall be construed as referring to any subsequent enactment passed in substitution for such repealed Act, unless it is otherwise manifested by the context."

91 Constitution of Niue, art 36. 
In 1993 the Foreign Affairs Act 1988, which provides for the conduct of relations between New Zealand and foreign states, was amended to include the "High Commissioner for New Zealand in Niue" within the definition of "head of mission". ${ }^{92}$ The significance of this amendment for Niue is that heads of mission may be appointed under the Foreign Affairs Act by the Governor-General, instead of by the Chief Executive of the Ministry of Foreign Affairs and Trade. ${ }^{93}$ It is not clear whether, in New Zealand law, this new provision impliedly amends s 9 of the Niue Constitution Act which otherwise remains in force. Nor is it clear whether the legal effect of s 9 was then adverted to by the New Zealand authorities. The Foreign Affairs Act does not extend to Niue as part of its law, and for the same reason as given above, should not be viewed as impliedly amending s 9 as it stands in Niue law.

Since 1993, the Representative of the New Zealand government in Niue has been appointed as "High Commissioner". ${ }^{94}$ In Niue, there were reservations about the appropriateness of the change in designation; seen as assimilating Niue to the position of an independent Commonwealth country and as involving a major departure from the role of the New Zealand Representative as the main point of liaison between Niue and New Zealand. There is also a perception that the change of designation led to a diminished New Zealand involvement in the conduct of Niue's external affairs. ${ }^{95}$ It seems likely, however, that the diminished involvement occurred for other reasons. ${ }^{96}$

Towards the end of 2000, the government of Niue decided to upgrade its representation in New Zealand by the appointment of a High Commissioner stationed in Wellington. ${ }^{97}$ At the time, a

92 See the Foreign Affairs Act 1988, s 2(aa): inserted by the Foreign Affairs Amendment Act 1993.

93 Under s 4(2) of the Foreign Affairs Act 1988, the procedure for the review of appointments put in place by the Secretary of Foreign Affairs and Trade in cl 5 of sch 8 of the Public Service Act 2020 does not apply to any appointment or reappointment of a head of mission. The cl 5 procedure allows for the review of appointments made by department chief executives where complaints are made about the appointment by people working in their department.

94 The terms of the New Zealand Representative Act 1981 (Niue) continue to apply to the person, who is for the time being, recognised by the government of Niue as the representative of the government of New Zealand in Niue, despite the change of designation from "New Zealand Representative" to "High Commissioner": see the definition of "New Zealand Representative" in s 2(1) of the New Zealand Representative Act 1981 (Niue).

95 See First Report of the Constitutional Review Committee, above n 31, at 44-45.

96 For example the declaration by New Zealand, above $\mathrm{n}$ 61, that treaties entered into by New Zealand do not extend to Niue, unless expressly signed, ratified, accepted, approved, or acceded to on behalf of Niue; and the fact that Niue began to be more active in its own external affairs, including by entering into bilateral agreements such as the Treaty Between the Government of the United States of America and the Government of Niue on the Delimitation of a Maritime Boundary [1997] PITSE 1 (signed 13 May 1997). In 2007 Niue established formal diplomatic relations with the People's Republic of China.

97 The appointment was made by the government of Niue, not by the Governor-General. Clause 10 of the Letters Patent relates specifically to the state of New Zealand, and not to the Realm of New Zealand - the Realm of New Zealand has no international identity and therefore no representatives. 
constitutional review was underway, and the Constitutional Review Committee ${ }^{98}$ saw this step as confirming that each government's representation in the other's territory signified no more than the conduct of diplomatic relations. It therefore recommended a review of s 9 of the Niue Constitution Act as it then applied, along with a review of s 6, relating to the conduct of Niue's external affairs as it then operated. This review was to be undertaken to see whether their then thrust was consistent with the Committee's emphasis on the need to maximise the interaction of the two countries under the special relationship, rather than to allow them to drift apart. ${ }^{99}$ The recommended review did not take place.

\section{THE CONSTITUTION OF NIUE}

The Niue Constitution is a Schedule to the Niue Constitution Act 1974 and so is part of New Zealand law. Accordingly, the obligations in the Constitution are binding on the New Zealand government. Further, s 4 of the Niue Constitution Act 1974 provides that New Zealand courts, departments and statutory authorities must, in exercising their powers under the Constitution, do so in accordance with the Constitution.

\section{A Article 60 - Audit Reports}

Article 60(1) of the Constitution provides that the Audit Office of New Zealand is the auditor of the Niue Government Account and of other public accounts. ${ }^{100}$ At least once a year, the Audit Office must prepare and forward to the Speaker of the Niue Assembly, for presentation to the Assembly, a report containing such information as is required to be submitted by any enactment in force in Niue. This will also include such other information relating to accounts required to be audited by the Audit Office as that office considers desirable. ${ }^{101}$ Under the laws of both New Zealand and Niue, the officers of the Audit Office are authorised and required to perform the functions laid upon them by the

98 The Constitutional Review Committee is a committee of the Niue Assembly, which meets ad hoc and infrequently.

99 First Report of the Constitutional Review Committee, above n 31.

100 It should be noted that at the time the Constitution was enacted, the Audit Office was the name given to the Controller and Auditor-General in New Zealand and any person exercising or performing any of their powers, duties or functions: see Public Revenues Act 1953. There is no longer an entity in New Zealand called the Audit Office; instead the work of the Controller and Auditor-General is now carried out by the Office of the Auditor-General, Audit New Zealand (a stand-alone business unit) and private sector auditing firms: see Controller and Auditor-General "About us" (2 July 2018) <www.oag.govt.nz>. In New Zealand law, all references in legislation to the Audit Office are now to be read as a reference to the Auditor-General: see Public Audit Act 2001, s 52. The Public Audit Act was not extended to Niue by the art 36 request and consent procedure, and so the change in nomenclature does not extend to references to the Audit Office in Niue law. Further, a change to the Constitution of Niue requires a super-majority in the Assembly, as well as the meeting of other formalities. Therefore, there is a discrepancy between the text of the Constitution and the reality of the present-day situation.

101 Constitution of Niue, art 60(2). 
Constitution in accordance with its provisions. ${ }^{102}$ It is implicit that they must perform those functions independently. ${ }^{103}$

The Niue Audit Regulations 1970 prescribe the responsibilities of the Auditor-General when auditing the accounts of the government of Niue. ${ }^{104}$ In performing an audit for Niue, the AuditorGeneral is essentially required to check that accounts have been properly kept and that there are sufficient controls in place to ensure sufficient accounting for all money and proper authorisation of expenditure. In contrast, when auditing public entities in New Zealand the Auditor-General will also look at compliance with statutory obligations relevant to financial statements and may also look at other non-financial information. ${ }^{105}$ In other words, the level of scrutiny to which the public accounts in New Zealand are subjected is higher than that to which the public accounts in Niue are subjected.

Presently, Niue pays for the audit. ${ }^{106}$ However, s 4(2) of the Niue Constitution Act states that New Zealand is required to carry out the audit even if Niue were not paying for it:

Where the Constitution provides that any New Zealand court or department of government or statutory authority shall perform any function or exercise any power in relation to Niue, that court, or, as the case may be, the officers of that department or the members and staff of that authority are by this Act authorised

and required to perform that function or exercise that power in accordance with the Constitution.

Whether in practice the question of which government pays for the audit of the Niue accounts will probably be of no significance, but it will be taken into account in fixing the amount of the "necessary economic assistance". 107

\section{B Article 36: Laws Extended to Niue at Request and Consent of Niue Assembly}

Article 36 of the Niue Constitution provides for New Zealand law to extend to Niue as part of the law of Niue only at the request and with the consent of the Niue Assembly. Article 36(1) provides that:

102 See the Niue Constitution Act, s 4(2).

103 The Controller and Auditor-General at one time occupied an identical position in the Cook Islands Constitution as the auditor of the Cook Islands government account and other public accounts. He was held to be a compellable witness before a New Zealand Commission of Inquiry constituted under the Commissions of Inquiry Act 1908: see Controller and Auditor-General v Davison [1996] 2 NZLR 278 (CA).

104 Niue Audit Regulations 1970, reg 3(4). Regulations were promulgated as SR 1970/103 of New Zealand.

105 See Audit New Zealand "Public sector auditing" (2 November 2015) <www.auditnz.govt.nz>.

106 The Niue Audit Regulations are from the colonial era; they stipulate that the government of Niue must pay: see reg 14.

107 The audit could be a matter for consideration in the context of s 7 of the Niue Constitution Act 1974. 
(1) No Act, and no provision of any Act, of the Parliament of New Zealand passed on or after Constitution Day shall extend to Niue as part of the law of Niue, unless-

(a) The passing of that Act or the making of that provision, so far as it extends to Niue, has been requested and consented to by resolution of the Niue Assembly; and

(b) It is expressly declared in that Act that the Niue Assembly has requested and consented to the enactment of that Act or of that provision.

Article 36(3) provides that a New Zealand Act that extends to Niue pursuant to the article has the same force and effect as if it were an Act of the Niue Assembly.

The request and consent provisions in art 36 of the Constitution have been used in relation to a few Acts of the New Zealand Parliament. ${ }^{108}$ Acts presently in force in Niue that were extended in that way are the Citizenship Act $1977^{109}$ and the Seal of New Zealand Act 1977. The provision was also used in s 41 (now repealed) of the Misuse of Drugs Act 1975.

\section{Seal of New Zealand Act 1977}

At the time it was passed, the Seal of New Zealand Act 1977 was extended to Niue by the request and consent of the Niue Assembly and became part of its law. Under s 3, however, the Seal of New Zealand can be used in relation to Niue only as part of the Realm of New Zealand and then only on the advice of New Zealand Ministers. However, the Niue government would first need to approve the application of the document in question to Niue. The Constitution states that there "shall be a Public Seal of Niue" (known as the Seal of Niue)" in such form or forms as the Cabinet from time to time approves." 110 The Seal is for use by the Speaker in authenticating public documents in relation to the government of Niue as a separate entity or for the execution of any document required by law to be executed under the Seal of Niue. ${ }^{111}$ At self-government, the Cabinet decided to continue to use the New Zealand Coat of Arms as the Seal of Niue as a temporary measure. ${ }^{112}$ As of December 2020, the Cabinet had not adopted an alternative Seal.

\section{Misuse of Drugs Act 1975}

In 1998, the Niue Assembly, apparently attempting to avoid needing to request and consent to each amendment to the Misuse of Drugs Act 1975 (of which there were many), passed an Act

108 Niue Constitution Act, art 36(2) applies to the extension of New Zealand subsidiary legislation.

109 As discussed above at Part III, A. The request and consent procedure has not been used for any amendments to that Act made by the New Zealand Parliament.

110 Constitution of Niue, art 15(1). See also Quentin-Baxter and McLean, above n 13, at 99-100.

111 Constitution of Niue, art 15(3)

112 The Seal of Niue is the New Zealand Coat of Arms inside a white circle, with "Public Seal of Niue" written above the Coat of Arms, and "Niue" written below. 
purporting to extend all amendments to the Misuse of Drugs Act 1975 in New Zealand law to Niue law unless the Assembly expressly indicated otherwise. The relevant section read: ${ }^{113}$

[s]ubject to [a resolution of the Niue Assembly to the contrary], the Misuse of Drugs Act 1975 of New

Zealand ... shall extend to and be in force in Niue as from time to time amended and in force in New

Zealand.

Like the Citizenship Act 1977 and the Seal of New Zealand Act 1977, the Misuse of Drugs Act 1975 had been extended to Niue by the request and consent of the Niue Assembly at the time it was enacted by the New Zealand Parliament. ${ }^{114}$ However, as was the case with the Citizenship Act 1977, no further amendments to that Act in New Zealand law were extended to Niue. The 1998 Act of Niue was intended to change that state of affairs.

There was commentary suggesting that the 1998 Act was unconstitutional on the grounds that it did not comply with the art 36 request and consent procedures. ${ }^{115}$ The question of the constitutionality of that Act is no longer an issue as both the Misuse of Drugs Act 1975 (Niue) and the Misuse of Drugs Act 1998 (Niue) have been repealed by the Misuse of Drugs Act 2007 (Niue) which makes no reference to the law of New Zealand. ${ }^{116}$

\section{Niue Law that Adopts New Zealand Law "for the time being in force"} 1 General

This Part addresses four provisions in the Niue Act 1966 in Niue law adopting the New Zealand law on a particular matter as the law of Niue. ${ }^{117}$ The matters are as follows:

(a) "an affidavit made out of Niue may, with the leave of the [High Court of Niue], be received in evidence if made before a solicitor of the High Court of New Zealand, or in any other manner which would make the affidavit admissible in civil proceedings in the High Court of New Zealand"; 118

113 Misuse of Drugs Act 1998, s 3(1)

114 Misuse of Drugs Act, s 41, which inserted a new section (s 689A) into the Niue Act 1966 and the Niue Act 1966 (Niue).

115 Townend, above n 128.

116 Misuse of Drugs Act 2007 (Niue), s 26.

117 A full list is provided in Appendix 2.

118 Niue Act 1966 (Niue), s 76. 
(b) in proceedings for nullity of marriage, the High Court of Niue "shall ... have and exercise in Niue the same jurisdiction as is possessed for the time being in New Zealand by the High Court"; 119

(c) "[t]he law of Niue as to prescription and the limitation of actions shall be the same as that which is in force for the time being in New Zealand"; 120

(d) "[a] copyright, design, patent, or trademark protected by New Zealand law shall be accorded the same protection by the courts of Niue as that available in New Zealand under the laws of New Zealand for the time being in force". ${ }^{121}$

So far as compatible with the Constitution, the law of Niue on each of the matters listed above is the law of New Zealand as in force for the time being. ${ }^{122}$ If that law is subsequently amended or repealed and substituted, the law of Niue changes likewise.

This practice of adopting New Zealand law "for the time being" raises an issue of constitutionality. It imports into the law of Niue statutes of the New Zealand Parliament, amendments to those statutes, and any corresponding regulations, without the Niue Assembly formally considering their application to Niue and consenting to their application.

There are at least three views as to whether or not the practice is constitutional. ${ }^{123}$ According to the first view, the practice is unconstitutional as ultra vires the Constitution. The second view also considers the practice unconstitutional, because it does not conform to the art 36 requirements for Acts of the New Zealand Parliament or New Zealand subordinate legislation to apply to Niue. According to the third view, the practice is constitutional as it is for the Niue Assembly to determine the law of Niue and the practice is consistent with the Assembly's authority as a sovereign legislature. The following paragraphs explain each view in more detail.

\section{The practice is unconstitutional as ultra vires the Constitution}

This view rests on the idea that the Constitution does not empower the Niue Assembly to abdicate from the exercise of the power found in art 28 of the Constitution of Niue to make law for Niue. Therefore, a law that purports to delegate the law-making power of the Niue Assembly to another entity is not within the constitutional power of the Assembly.

119 Niue Act 1966 (Niue), s 531; now the Family Law Code s 16. The law of New Zealand as at 1 May 2019 is in the Family Proceedings Act 1980 ss $27-31$.

120 Niue Act 1966 (Niue), s 706(1).

121 Niue Act 1966 (Niue), s 737

122 The New Zealand law concerned must be read in the setting of New Zealand law as a whole, including the Interpretation Act 1999, ss 22 and 23.

123 These views do not rely on the law that is being adopted "for the time being", being the law of New Zealand: It could be the law of any jurisdiction (for example, of New South Wales or of England or of Samoa). 
The 1969 decision of the Seychelles Court of Appeal in Kim Koon \& Co Ltd v Republic of Seychelles exemplifies this reasoning. ${ }^{124}$ That case dealt with the sufficiency of evidence as to the country of origin of certain products for the purposes of determining whether they were legally imported into Seychelles. As to the content of the law of evidence in Seychelles, s 12 of the Seychelles Evidence Ordinance (as amended by s 3 of the Seychelles Judicature Ordinance 1962) provided:

12. Except where it is otherwise provided by special laws now in force in the Colony or hereafter enacted, the English Law of Evidence for the time being shall prevail.

Counsel made mention of amendments made to the English law of evidence by the English Criminal Evidence Act 1965. The Court was faced with the question of whether or not that Act applied to Seychelles. The Court found that it did not: ${ }^{125}$

\footnotetext{
We have no doubt that it is not competent for the Seychelles Legislature to delegate the power to legislate, and that so far as section 12 of the Evidence Ordinance as amended may purport to apply to Seychelles future amendments of the English law of evidence, it is inoperative. In our judgment the effect of the section [ie s 12] is to apply to Seychelles the English law of evidence as it stood on the 15th October, 1962, the date of enactment of the Seychelles Judicature Ordinance, 1962. Accordingly, the Criminal Evidence Act 1965, does not apply in Seychelles.
}

Seychelles was a colony and a subordinate legislature until 1976, but since independence Kim Koon has been seen as a precedent to be followed in the courts of the independent state. ${ }^{126}$

\section{Non-conformity with art 36 of the Constitution}

The second view rests on interpretation of art 36 of the Constitution of Niue. According to this view, each amendment to Niue law by the New Zealand Parliament must follow exactly the procedures laid down in art 36(1) and art 36(2). In respect of statutes, art 36(1) requires both that any enactment of the New Zealand Parliament extending to Niue be requested and consented to by the Niue Assembly, and that the enactment expressly declares such request and consent. In respect of subordinate legislation, art 36(2) requires that the Act pursuant to which the subordinate legislation is made already extends to Niue, that the extension of the subordinate legislation be requested and consented to by the Niue Cabinet of Ministers, and that the subordinate legislation expressly declares such request and consent.

124 Kim Koon \& Co Ltd v Republic of Seychelles (1969) SCAR 60.

125 At 64 (emphasis added).

126 See the view of Seychelles leading jurist A Sauzier J in André Sauzier Sauzier on Evidence (2nd ed, City Print, Wellington, 2011) at 2. See also M Twomey Legal Métissage in a Micro-Jurisdiction: The Mixing of Common Law and Civil Law in Seychelles (City Print, Wellington, 2017) at 153. 
To the extent that the provisions of the Niue Act 1966 (Niue) noted above circumvent those requirements, they conflict with art 36 . Given that the Constitution is the supreme law of Niue, ${ }^{127}$ art 36(1) and (2) must prevail. ${ }^{128}$ As such, it might be suggested that they must be repealed. Despite the inconvenience, the Assembly must consider, in the case of each and every enactment of the New Zealand Parliament or Regulation made by the New Zealand executive which alters the law of New Zealand in respect of areas where the Niue Act 1966 (Niue) purports to adopt New Zealand law "for the time being" (for example, each enactment that changes the law of copyright), whether or not it should extend to Niue by request and consent. ${ }^{129}$

\section{The practice is constitutional as it is for the Niue Assembly to determine the law of Niue and the practice is consistent with the Assembly's authority}

The third view also rests on the interpretation of art 36 but favours a less formal and more purposive interpretation of that article. It rests on the proposition that the Niue Assembly has complete authority to make laws for Niue as it sees fit, so long as they are consistent with the Constitution. The above provisions of the Niue Act 1966 (Niue) are consistent with the Constitution because the request and consent provisions in art 36 of the Constitution of Niue only apply to situations where the New Zealand Parliament is explicitly making law "for Niue". When the Niue Assembly adopts New Zealand law on a matter, it is the Niue Assembly itself that initially acts (or, in the case of laws carrying over from Constitution Day, omits to repeal) and the art 36 provisions do not need to be followed. It is therefore constitutional for the Niue Assembly to legislate to adopt all New Zealand amendments to, and regulations in respect of, a particular law past and future.

The intention of art 36 is to prevent the New Zealand Parliament from legislating for Niue as if Niue were still a colony. The "for the time being" provisions of the Niue Act 1966 (Niue) do not run counter to that intention. At any point in the future, the Niue Assembly can repeal the provisions. As the Niue Assembly retains full legislative authority, the purpose of art 36 is not defeated. ${ }^{130}$

\section{Conclusion}

In summarising the views described above, it could be said that the first view is the purist's view, the second the formalist's, and the third the pragmatist's. The position taken here is that the third view

127 Niue Constitution Act, s 4.

128 This is the view taken by Andrew Townend in relation to the Misuse of Drugs Act 1998 (discussed above at Part IV B2) "Drugs-bust in Niue: The Misuse of Drugs Act 1998 and the Constitution" (2002) Revue Juridique Polynésienne numéro hors serie (vol 2) 109.

129 Townend, above n 128, at 112-113.

130 A current example of this legislative practice in New Zealand is in the Constitution Act 1986, s 4(1): "Where, under the law of the United Kingdom, the royal functions are being performed in the name and on behalf of the Sovereign by a Regent, the royal functions of the Sovereign in right of New Zealand shall be performed in the name and on behalf of the Sovereign by that Regent." 
is the preferable one: it takes into account the actual situation in a small state with a legislature and administration that have limited capacity and promotes a purposive and practical interpretation of the Constitution.

If the "for the time being in force" provisions are treated as ultra vires the Constitution or as in violation of the Constitution, the effect would be that the Niue law on the matters to which the above relates would probably be held to be the same as New Zealand law on Constitution Day. ${ }^{131}$ The Niue Assembly would be free to amend those laws as it saw fit.

\section{$D$ Article 55 and Appeals to the Judicial Committee of the Privy Council}

Article 55 of the Niue Constitution provides:

(1) Except as provided in subclause (2) of this Article, or as may be provided by enactment, the determination of the Court of Appeal shall be final.

(2) Nothing in this Article shall limit the right of Her Majesty in Council, upon the petition of any person aggrieved by any decision of the Court of Appeal to admit that person's appeal therefrom upon such conditions as Her Majesty in Council shall think fit to impose.

Article 55(2) appears to have the intention of specifically leaving open access to further appeals by explicitly not extinguishing the royal prerogative to permit appeals to the Crown in Council. ${ }^{132}$ No such appeals have ever been made from the Niue courts.

In recent years there have been appeals made to the Judicial Committee of the Privy Council in London from determinations of the Cook Islands Court of Appeal, ${ }^{133}$ presumably ${ }^{134}$ under a provision of the Cook Islands Constitution which bears some similarities to art 55 of the Niue Constitution: ${ }^{135}$

(2) There shall be a right of appeal to Her Majesty the Queen in Council, with the leave of the Court of Appeal, or, if such leave is refused, with the leave of Her Majesty the Queen in Council, from

131 Assuming that law is compatible with the Constitution of Niue. See art 71 of the Constitution provides (emphasis added):

Subject to this Constitution,-

The existing law shall, until repealed, and subject to any amendment thereof, continue in force on and after Constitution Day.

132 Compare New Zealand law which explicitly extinguished the prerogative in the Supreme Court Act 2003, s 42.

133 The descendants of Utanga and Arerangi Tumu $v$ The descendants of Iopu Tumu [2012] UKPC 34; and Baudinet v Tavioni [2012] UKPC 35.

134 The Judicial Committee of the Privy Council does not discuss its jurisdiction to hear the appeal in either judgment.

135 Constitution of the Cook Islands, art 59. 
judgments of the Court of Appeal in such cases and subject to such conditions as are prescribed by

Act.

There are two potentially important differences between art 59 of the Cook Islands Constitution and art 55 of the Niue Constitution: the Cook Islands provision explicitly empowers Her Majesty the Queen in Council to hear appeals, while the Niue provision only leaves in place any existing power. Additionally, the Cook Islands provision provides for legislation to prescribe the conditions of appeal. The Privy Council (Judicial Committee) Act 1984 (Cook Islands) does that by extending to the Cook Islands a 1910 Order in Council regulating appeals to Her Majesty in Council from New Zealand courts. ${ }^{136}$ There is no such provision in Niue law.

Accordingly, there is a question as to whom or to what "Her Majesty in Council" in art 55(2) of the Niue Constitution refers. It might refer to the Privy Council of colonial times: the wording of the (since repealed) Supreme Court Act 2003, referring to "Her Majesty in Council" when abolishing appeals from the New Zealand courts to the Judicial Committee of the Privy Council would tend to suggest that:

\section{Ending of appeals to Her Majesty in Council}

(1) No appeal to Her Majesty in Council lies or may be brought from or in respect of any civil or criminal decision of a New Zealand court made after 31 December 2003 -

(a) whether by leave or special leave of any court or of Her Majesty in Council, or otherwise; and

(b) whether by virtue of any Act of Parliament of the United Kingdom or of New Zealand, or the Royal prerogative, or otherwise.

Alternatively, it might refer to the Executive Council constituted under the Letters Patent Constituting the Office of Governor-General to advise the Queen "in the Government of [the] Realm of New Zealand". ${ }^{137}$ The Executive Council consists of those eligible for appointment under the Constitution Act $1986^{138}$ ie members of the New Zealand Parliament. ${ }^{139}$ Additionally, it is not clear which body would advise the Executive Council on appeals from Niue courts. ${ }^{140}$

136 Privy Council (Judicial Committee) Act 1984. The Act provides that the Order shall have effect as if it has been amended by substituting Cook Islands courts for New Zealand courts. See Alex Frame "The Cook Islands and the Privy Council " (1984) 14 VUWLR 311; and Alex Frame "Cook Islands appeals in the Privy Council" [2013] NZLJ 132.

137 Letters Patent Constituting the Office of Governor-General of New Zealand 1983, cl 7.

138 Letters Patent Constituting the Office of Governor-General of New Zealand 1983, cl 8.

139 Constitution Act 1986, s 6(1).

140 Before the change in the structure of universities in 1989, there was the possibility of appeal on academic matters to the Governor-General as Visitor. The practice in such cases was for the Governor-General to 
As a matter of practicality, it appears that art 55 will result in any appeals from Niue being resolved by the Judicial Committee of the Privy Council: the website of that institution indicates that it has jurisdiction to hear appeals from Niue. ${ }^{141}$

\section{NIUE ACT 1966 IN NEW ZEALAND LAW}

For the reasons described in the introduction, there is one version of the Niue Act 1966 in New Zealand law and another version in Niue law. The versions were identical on Constitution Day but have since diverged because they have been amended by the New Zealand Parliament and the Niue Assembly respectively. This Part examines features of the Niue Act 1966 in New Zealand law and describes the position in the corresponding Niue statute where that is of practical interest.

\section{A Provisions Concerning the High Court of Niue}

Several provisions in the Niue Act 1966 in New Zealand law govern the powers of the High Court of Niue. Since Constitution Day, the High Court of Niue has derived its powers from the Constitution, ${ }^{142}$ and not from the New Zealand version of the Niue Act 1966. The provisions in the New Zealand law are therefore redundant. Specifically:

(a) Section 127 of the Act (New Zealand version) provides for the High Court of Niue to enforce injunctions of the High Court of New Zealand by way of proceedings for contempt if the High Court files a memorial in the High Court of Niue. The High Court of New Zealand cannot direct the High Court of Niue to enforce judgments of New Zealand courts. However, s 127 of the Niue Act 1966 (Niue) directs the Niue Court to enforce such judgments.

(b) Sections 305 to 311 of the Act (New Zealand) empower the High Court of Niue to do certain things in relation to the extradition of persons from Niue to New Zealand or to the Cook Islands. Those provisions are necessarily within the unfettered legislative power of the New Zealand Parliament but being outside its jurisdiction to enforce, the law will have no effect. Because they give the impression that these matters are under the control of the New Zealand legislature, they should be repealed. These sections were repealed in Niue by the Extradition Act 2007 (Niue).

(c) Sections 608 to 610 and 619 of the Act (New Zealand) provide for the High Court of Niue to issue warrants for the removal of persons from Niue to New Zealand. Section 611 deals with the detention in New Zealand hospitals of persons removed from Niue to New Zealand under medical orders made by the High Court of Niue. That section does not currently reflect

appoint a committee to advise on the matter referred to him or her as Visitor. This may by analogy indicate a process to be followed. Also of interest is Joseph on Constitutional and Administrative Law (5th ed, Thomson Reuters, Wellington, 2021) at 803: "The Queen now has a relationship to the Executive Council similar to that which she has with her Privy Council".

141 "Role of the JCPC" Judicial Committee of the Privy Council <www.jcpc.uk>.

142 Specifically, from arts 37 and 38 of the Constitution of Niue. 
the fact that such removals occur under Niue law, and not under New Zealand law. Accordingly, the provisions in the New Zealand law should be recast to give clear authority for detention in New Zealand in such circumstances. Section 619(2) does not exist in Niue.

(d) Sections 720(1) and (2) of the Act (New Zealand) empower various persons in Niue to take statutory declarations. A number of those persons listed may no longer take statutory declarations in Niue under Niue law. Section 720 was substantially amended for Niue by the Legislation (Correction of Errors and Minor Amendments) Act 2004 (Niue).

It would be appropriate to retain in New Zealand law only those provisions in the Niue Act 1966 that require New Zealand legislation to be effective. For example, the provisions empowering New Zealand courts, departments and statutory authorities to perform in New Zealand or outside New Zealand or Niue (by a New Zealand ship or aircraft) functions they are empowered to perform in Niue by virtue of Niue law.

\section{B Spent Provisions}

A number of provisions in the Niue Act 1966 (NZ) provide that New Zealand statutes apply in the law of Niue. The provisions are ss 683A, 686, 689, 690, 694, 695, 698, 699 and 702. On Constitution Day, those statutes were part of the existing law of Niue, and therefore amenable to amendment or repeal by the Niue Assembly. Accordingly, the provisions in the Niue Act (NZ) are spent and should be repealed in the interest of keeping New Zealand law up to date. The corresponding provisions have been repealed in Niue, and in some cases replaced.

\section{Provisions that Assume that Niue is Part of New Zealand}

A number of provisions in the Niue Act 1966 in New Zealand law are drafted as if Niue is still part of the state of New Zealand. Those provisions should be amended to reflect Niue's autonomous status. Specifically:

(a) Section 128 provides that ss 30 to 32 of the Senior Courts Act 2016 (which provide for the High Court of New Zealand to appoint Commissioners to take oaths outside of New Zealand) must be construed to operate as if Niue were a place outside the jurisdiction of the High Court of New Zealand. That section is otiose given the provisions of the Senior Courts Act 2016. The provision has been repealed in Niue law, and should be repealed in New Zealand law.

(b) Sections 312 to 319 of the Act relate to the extradition of persons from New Zealand to Niue. These sections were repealed in Niue by the Extradition Act 2007 (Niue).

\section{Enforcement of Judgments under s 95 of the Niue Act 1966}

Section 95 of the Niue Act 1966 provides for the enforcement of Niue judgments in New Zealand. The provision appears to be less restrictive in relation to Niue judgments than judgments from other jurisdictions; this is appropriate given that Niue is in the Realm of New Zealand. For example, an application for the enforcement of an Australian judgment is subject to time and other limitations, and 
must be in the form prescribed by regulations made by the Governor-General. ${ }^{143}$ In contrast, an application for the enforcement of a Niue judgment can be made by filing a memorial of the judgment containing certain particulars, authenticated by the seal of the High Court of Niue, in any office of the High Court of New Zealand.

In Niue law, s 95 of the Niue Act 1966 provides for the enforcement of non-Niue judgments in Niue. There is no conflict between the provision in Niue and New Zealand law as the subject-matter of the Niue provision does not overlap with the subject-matter of the New Zealand provision.

\section{E Provisions for the Transfer of Convicted Persons}

Sections 243 to 245 of the Niue Act 1966 (NZ) provide for a person sentenced in Niue to be transferred to New Zealand and imprisoned in New Zealand as if they had been sentenced by the New Zealand courts. ${ }^{144}$ The provisions do not appear to comprehensively provide for the detention of such prisoners in New Zealand and as such may not be effective.

In particular, the provisions rely heavily on processes and statutory bodies set out in the Criminal Justice Act 1954. That Act was replaced by the Criminal Justice Act 1985 which in turn was replaced by the Criminal Procedure Act 2011. The current legislation is significantly different from the Criminal Justice Act 1954. Therefore, it is unclear whether the particular references to the Criminal Justice Act 1954 directly correspond to provisions in the Criminal Procedure Act 2011.

Another issue is that s 244 provides for the Minister of Justice to release a prisoner who is a Niuean and allow that prisoner to remain in New Zealand after release. ${ }^{145}$ It is not clear how this provision would interact with New Zealand's immigration laws.

\section{F Superannuation for Niuean Public Servants}

Sections 669 and 670 of the Niue Act relate to employment in the New Zealand government service and in the Niue public service, and the contribution to the Government Superannuation Fund by employees of the Niue public service. The provisions are spent except in relation to Niue public servants employed before 9 June 1995. ${ }^{146}$

143 See Trans-Tasman Proceedings Act 2010, ss 52-68. The procedure set out for enforcement in those sections only applies if the judgment is a "registrable Australian judgment" as defined in s 54 of the Trans-Tasman Proceedings Act.

144 A case on point is Attorney-General v Pioiva Niue Court of Appeal 433/81, 12 May 1999 reported in Niue Legislation Supplement and Constitutional Cases 1998-2001 at 141.

145 The person may well be a New Zealand citizen, in which case, they would be able to remain in New Zealand as of right. However, "Niuean" is defined in the Niue Act 1966 as a person belonging to the aboriginal race of Niue. Therefore, there is a possibility that the person could be Niuean but not a New Zealand citizen.

146 Government Superannuation Fund Amendment Act 1995, s 6. 


\section{OTHER LEGISLATION}

\section{A Portability of Superannuation and Veterans' Support}

Under the New Zealand Superannuation and Retirement Income Act 2001 and Veterans' Support Act 2014, superannuation and veterans' pensions can be received by New Zealand citizens in Niue. As originally enacted, an applicant for superannuation or a veteran's pension needed to be ordinarily resident in New Zealand at the time of their application. In 2015 the provisions were amended ${ }^{147}$ to provide that an application could be made from Niue, provided that the applicant met certain residency requirements ( 10 years resident and present in New Zealand since age 20, and five years resident and present since age 50$)^{148}$ before leaving New Zealand to live in Niue. ${ }^{149}$

The Social Assistance (Residency Qualification) Legislation Act, which came into force in January $2019,{ }^{150}$ allows a person to meet the latter requirement (five years resident and present since age 50) by being resident and present in New Zealand, the Cook Islands, Niue or Tokelau. ${ }^{151}$ The effect of the amendment on eligibility for superannuation and veterans' pensions is that a person who, for example, moves to Niue at the age of 50 will be required to have been resident and present in New Zealand for 10 years since the age of 20. This is in addition to being required to be resident and present in Niue for five years since the age of 50. In contrast, a person resident and present in New Zealand between the ages of 45 and 55 would meet the requirements for a pension or superannuation as a result of those 10 years of residence alone. This does not reflect the free association relationship between Niue and New Zealand. In addition, it creates an incentive for Niueans to live in New Zealand; this is against the economic interests of Niue which needs its people and their skills to be in Niue.

\section{B Crimes Act - Law of Treason}

The Queen in right of New Zealand is the Head of State of Niue and the Governor-General is Her Majesty's representative in relation to Niue. ${ }^{152}$ Niue is part of the Realm of New Zealand.

The New Zealand law as to treason and related offences is drafted exclusively in terms of a person's allegiance, not citizenship. However, in a commentary on the section, Adams concluded that the result

147 Social Assistance (Portability to Cook Islands, Niue and Tokelau) Act 2015.

148 New Zealand Superannuation and Retirement Income Act 2011, s 8.

149 Section 31(4); and Veterans' Support Act 2014, s 191(4).

150 Social Assistance (Residency Qualification) Legislation Act Commencement Order 2018

151 Social Assistance (Residency Qualification) Legislation Act 2018, s 5: amending s 8(c) of the New Zealand Superannuation and Retirement Income Act 2011.

152 Constitution of Niue, art 1. 
was likely to be much the same. ${ }^{153}$ Section 73 of the Crimes Act 1961 defines treason as one of six actions ${ }^{154}$ committed by anyone "owing allegiance to the Sovereign in right of New Zealand", whether committed within or outside New Zealand. New Zealand citizens, whether in New Zealand, or Niue or outside both countries, clearly owe allegiance to "the Sovereign in right of New Zealand". It is not clear, however, whether some of the references to "New Zealand" in s 73 are to the Realm of New Zealand (in which case the term would include Niue) or to New Zealand as a territorial description (in which case it would not). In any case, since Niue became self-governing, the specific reference to "the Government of New Zealand" in s 73(e) cannot be taken as including the government of Niue.

It would be consistent with the relationship of free association between Niue and New Zealand for the two governments to agree to ensure that in both the law of New Zealand and the law of Niue it is treasonable for New Zealand citizens (and others owing local allegiance) to use force against either country or its government. The scope of seditious offences in the law of each country should also be examined. The law of Niue does not make treason a crime, but it is an offence punishable by imprisonment for a term not exceeding two years to speak seditious words, or publish a seditious libel or be a party to a seditious conspiracy. ${ }^{155}$ An ingredient of each of these offences is a "seditious intention" which is defined as an intention, among other things: ${ }^{156}$

(a) to excite disaffection against Her Majesty, or against the Parliament or Government of New Zealand, or against the Government of Niue; or

(b) to procure otherwise than by lawful means the alteration of any matter affecting the laws, Government, or Constitution of Niue.

153 Francis Adams (ed) Criminal Law and Practice in New Zealand (Sweet \& Maxwell (NZ) Ltd, Wellington, 1964) at 149 (The point is not dealt with in the most recent edition.).

154 Section 73 reads:

Every one owing allegiance to the Sovereign in right of New Zealand commits treason who, within or outside New Zealand, -

(a) kills or wounds or does grievous bodily harm to the Sovereign, or imprisons or restrains her or him; or

(b) levies war against New Zealand; or

(c) assists an enemy at war with New Zealand, or any armed forces against which New Zealand forces are engaged in hostilities, whether or not a state of war exists between New Zealand and any other country; or

(d) incites or assists any person with force to invade New Zealand; or

(e) uses force for the purpose of overthrowing the Government of New Zealand; or

(f) conspires with any person to do anything mentioned in this section.

155 Niue Act 1966 (Niue), s 130.

156 Niue Act 1966 (Niue), s 129(1) and (2). 
Niue law therefore recognises that certain kinds of acts directed against New Zealand, as distinct from Niue, constitute a seditious offence. It would be consistent with the relationship of free association for the governments of New Zealand and Niue to agree to ensure that there is sufficient provision in their respective criminal laws making it an offence in each country to commit treasonable or seditious acts against the other country or its government. ${ }^{157}$

\section{Royal Titles Act 1974}

The Royal Titles Act 1974 was extended to Niue as part of its law before self-government. ${ }^{158}$ In New Zealand law, the Act prescribes the royal styles and title of Her Majesty 159 "for use in relation to New Zealand and all other territories for whose foreign relations Her Government in New Zealand is responsible". 160

This formula is now outdated in respect of Niue as the government of Niue is now responsible for its own foreign relations. This was recognised by the 2004 amendment to the Niue law to retain the styles and titles but specify for use in relation to Niue. The law in New Zealand should be amended to prescribe that the royal styles and titles set out in the Act are for use in relation to the Realm of New Zealand, including the self-governing states of the Cook Islands and Niue, and Tokelau and the Ross Dependency.

\section{Royal Succession Act 2013}

The passage of the Royal Succession Act 2013 in New Zealand law raised the interesting question as to where power lies in determining the identity of the Sovereign in right of New Zealand. While it is beyond the scope of this article to answer that question, some observations are offered on the subject.

In 2011 at the Commonwealth Heads of Government Meeting, it was agreed that changes would be made to the rules of succession to the throne in order to remove the precedence of male heirs in the line of succession. ${ }^{161}$ The United Kingdom legislated for such a change, but the government in the United Kingdom took the position that the change could not come into effect until all 16 of the

157 Noting that the provisions relating to seditious offences in the criminal law of New Zealand were repealed in 2008: Crimes (Repeal of Seditious Offences) Amendment Act 2007.

158 Royal Titles Act 1974, s 3.

159 Elizabeth the Second, by the Grace of God Queen of New Zealand and Her Other Realms and Territories, Head of the Commonwealth, Defender of the Faith.

160 Royal Titles Act 1974, s 2.

161 For a discussion of the background to the changes, see Quentin-Baxter and McLean, above n 13, at 58-61. 
countries of which the Queen is the Head of State ${ }^{162}$ passed any necessary legislation or made any other necessary changes. ${ }^{163}$ There is no legal requirement that the United Kingdom receive such consent from the other Realms, but the government of the United Kingdom treated it as a moral requirement. ${ }^{164}$ Bonney and Morris also note the practical consideration that it would be undesirable to have different succession rules across Queen Elizabeth II's Realms, which might result in different realms having different monarchs in the future. ${ }^{165}$

The New Zealand Parliament passed the Royal Succession Act 2013 to implement the agreed changes to the succession. ${ }^{166}$ The New Zealand government consulted with the government of Niue at the time the 2013 Act was being prepared but the Royal Succession Act 2013 was not extended to Niue as part of its law.

In fact, no law regulating the succession to the role of Sovereign in right of New Zealand exists in the law of Niue. ${ }^{167}$ Section 5 of New Zealand's Constitution Act 1986 provides for succession on the demise of the Sovereign in right of New Zealand, providing that succession is:

162 The 16 Realms are Antigua and Barbuda, Australia, the Bahamas, Barbados, Belize, Canada, Grenada, Jamaica, New Zealand, Papua New Guinea, Saints Kitts and Nevis, Saint Lucia, Saint Vincent and the Grenadines, Solomon Islands, Tuvalu and the United Kingdom.

163 This view is reflected for example in United Kingdom Deputy Prime Minister's Office "Royal Succession Rules will be changed" (press release, 4 December 2012). The government of New Zealand coordinated formal consent from each Realm country. Australia, Barbados, Canada, the Grenadines, New Zealand, St Kitts and Nevis, St Vincent and the United Kingdom legislated for the changes. Antigua and Barbuda, Bahamas, Belize, Grenada, Jamaica, Papua New Guinea, St Lucia, Solomon Islands and Tuvalu determined legislation was not necessary, taking the view that any references in their respective constitutions to "the Sovereign" were references to the reigning monarch in the UK: see Quentin-Baxter and McLean, above n 13, at 61 .

164 Norman Bonney and Bob Morris "Tuvalu and You: The Monarch, the United Kingdom and the Realms" (2012) 83 The Political Quarterly 368 at 368. The preamble to the Statute of Westminster 1931 stated that:

it would be in accord with the established constitutional position of all the members of the Commonwealth in relation to one another that any alteration in the law touching the succession to the Throne ... shall hereafter require the assent as well of the Parliaments of all the Dominions as of the Parliament of the United Kingdom.

There is useful discussion of the legal status of that preambular passage in Anne Twomey "Changing the Rules of Succession to the Throne" (Sydney Law School, Legal Studies Research Paper No 11/71, October 2011).

165 Bonney and Morris, above n 164. This practical point does not change that fact that it is for each of the Realms to determine its own head of state; a point that was confirmed by Queen Elizabeth II at the time of the 1999 referendum on the head of state in Australia: Windsor Castle "Australian Referendum 1999 - Statement by Her Majesty the Queen" (press release, 6 November 1999).

166 The Royal Succession Act 2013 also made a few other changes relating to royal marriages.

167 This is also true in relation to the law of the Cook Islands. 
determined in accordance with the enactment of the Parliament of England intituled The Act of Settlement

(12 \& 13 Will 3, c 2) and any other law relating to the succession to the Throne.

The Royal Succession Act 2013 is such a law, and the Act of Settlement is part of the law of the state of New Zealand by virtue of the Imperial Laws Application Act $1988 .{ }^{168}$ It is not part of the law of Niue.

It might be argued that s 5 of the Constitution Act 1986 governs succession only in relation to the Sovereign in right of the State of New Zealand. However, the defining feature of the Realm is the common Head of State. ${ }^{169}$

Quentin-Baxter and McLean suggest that in the Constitution of Niue (as well as in the laws of the Cook Islands and Tokelau), references to the "Sovereign in right of New Zealand":170

can be seen as importing by reference any change that may be made in New Zealand law in respect of the

Sovereign, if it is clearly pertinent to her role in all part of the Realm.

However, this suggestion seems to run counter to the self-government of Niue, and to art 36 of the Constitution of Niue, which removed the law-making powers of the New Zealand Parliament in respect of Niue, and provides that New Zealand laws can extend to Niue only by request and consent.

\section{CONCLUSION}

The law of Niue has its origins in the law of New Zealand but is self-evidently different from the law of New Zealand. The relationship between the laws of the two countries is an intriguing one, not least because both countries are within the Realm of New Zealand. There is a focus in this article on formal law, which is sustained by the fact that the Constitution of Niue is entrenched and as a supreme law, very difficult to change.

168 Prior to the Imperial Laws Application Act 1988, it was by virtue of the English Laws Act 1908.

169 See discussion in Quentin-Baxter and McLean, above n 13, at 104-112; Andrew Townend "The Strange Death of the Realm of New Zealand: The Implications of a New Zealand Republic for the Cook Islands" (2003) 34 VUWLR 571 at 581; and see generally the Letters Patent Constituting the Office of GovernorGeneral of New Zealand 1983.

170 For example in art 1, which vests the executive authority of Niue in "Her Majesty the Queen in right of New Zealand"; and Quentin-Baxter and McLean, above n 13, at 112. They say this does not apply, however, to a change in the law of New Zealand that "would bring to an end the Sovereign's role as New Zealand's Head of State". 


\section{APPENDIX 1}

(See $n 16$ of the text)

New Zealand Acts which applied to Niue on Constitution Day which are still in force as Niue law on 1 April 2019

\begin{tabular}{|c|c|c|}
\hline Act & $\begin{array}{l}\text { Still in force in } \\
\quad \text { NZ? }\end{array}$ & $\begin{array}{l}\text { Amended by Niue } \\
\text { Assembly? }\end{array}$ \\
\hline Administration Act 1969 & Yes & $\begin{array}{l}\text { See now the Family } \\
\text { Law Code } 2007 \text { ss } \\
154-218\end{array}$ \\
\hline $\begin{array}{l}\text { Adoption Act } 1955 \text { (Sections 16(1), 16(2) and } \\
\text { 20(6) only: see Niue Amendment Act (No 2) } \\
1968 \text { ss } 99 \text { and 100) }\end{array}$ & Yes & $\begin{array}{l}\text { See now the Family } \\
\text { Law Code } 2007 \text { ss } 35 \\
\text { and } 37\end{array}$ \\
\hline Arbitration Act 1908 & No & Yes \\
\hline Arbitration Amendment Act 1938 & No & Yes \\
\hline $\begin{array}{l}\text { Arbitration Clauses (Protocol) and the Arbitration } \\
\text { (Foreign Awards) Act } 1933\end{array}$ & No & Yes \\
\hline Atomic Energy Act 1945 & Yes & Yes \\
\hline Bills of Exchange Act 1908 & Yes & Yes \\
\hline Carriage by Air Act 1967 & No & Yes \\
\hline Chattels Transfer Act 1924 & No & Yes \\
\hline Cheques Act 1960 & Yes & Yes \\
\hline Commissions of Inquiry Act 1968 & Yes & Yes \\
\hline Consular Privileges and Immunities Act 1971 & Yes & Yes \\
\hline Continental Shelf Act 1964 & Yes & Yes \\
\hline Crown Proceedings Act 1950 & Yes & Yes \\
\hline Customs Act 1966 & No & Yes \\
\hline Death by Accidents Compensation Act 1952 & Yes & Yes \\
\hline Diplomatic Privileges and Immunities Act 1968 & Yes & Yes \\
\hline $\begin{array}{l}\text { General Agreement on Tariffs and Trade Act } \\
1948\end{array}$ & No & No \\
\hline Geneva Conventions Act 1958 & Yes & No \\
\hline Guardianship Act 1968 & No & $\begin{array}{l}\text { See now the Family } \\
\text { Law Code } 2007 \text { ss } \\
38-68\end{array}$ \\
\hline
\end{tabular}




\begin{tabular}{|l|l|l|}
\hline Incorporated Societies Act 1908 & Yes & Yes \\
\hline International Finance Agreements Act 1961 & Yes & No \\
\hline Marine Insurance Act 1908 & Yes & No \\
\hline Mercantile Law Act 1908 & No & Yes \\
\hline Merchandise Marks Act 1954 & No & Yes \\
\hline Minors' Contracts Act 1969 & No & Yes \\
\hline Niue Act 1966 & Yes & Yes \\
\hline Niue Amendment Act (No 2) 1968 & Yes & Yes \\
\hline Occupiers' Liability Act 1962 & Yes & Yes \\
\hline Partnership Act 1908 & No & Yes \\
\hline Property Law Act 1952 & No & No \\
\hline Royal Titles Act 1974 & Yes & No \\
\hline Sale of Goods Act 1908 & No & $\begin{array}{l}\text { Yes } \\
\text { Law Code 2007 ss } \\
117-149\end{array}$ \\
\hline Trustee Act 1956 & No & Yes \\
\hline United Nations Act 1946 & Yes & Yes \\
\hline Visiting Forces Act 1939 & No & No \\
\hline Wills Act 1837 & & No the Family \\
\hline Wills Act Amendment Act 1852 & & So ss \\
\hline
\end{tabular}




\section{APPENDIX 2}

(See $n 117$ of the text)

Legislation of Niue which refers to legislation of New Zealand

\begin{tabular}{|l|l|}
\hline Niue Legislation & New Zealand Legislation \\
\hline Civil Aviation Act, s 52 & Civil Aviation Rules \\
\hline Communications Act, s 30 & Reference to NZ regs \\
\hline Criminal Code, s 132 & Medical custody \\
\hline Customs Regulations, reg 133(1) & Customs agents licence \\
\hline Family Code, ss 16, 68 & Nullity of marriage; Children \\
\hline Geneva Conventions Act, s 5(4), s 7(2) & Legal aid; Military custody \\
\hline Land Court Rules, rr 27(4)(b), 27(5) & Oaths \\
\hline Niue Bank Act, ss 40A, 84A, 84M, 84N & $\begin{array}{l}\text { Banking agent; New Zealand bank; } \\
\text { Disclosure; Compliance }\end{array}$ \\
\hline Niue Act, ss 76, 737 & Affidavits; Intellectual property \\
\hline Visiting Forces Act, s 3(2) & Witnesses \\
\hline
\end{tabular}

